\title{
ERIARVOISUUS ON PÄIVÄN SANA
}

\section{Pääkirjoitus}

ojanus

Vaikka Suomessa ja etenkin sosiaalipolitiikan ja sosiaalityön tutkimuksessa on keskusteltu eriarvoisuudesta jo pitkään, on viime vuosina eriarvoisuus noussut aiempaa enemmän myös politiikan ja median agendalle. Mediassa kirjoitetaan yhä useammin heikossa tai haavoittuvassa asemassa olevista ihmisistä. Yle esimerkiksi raportoi 27-vuotiaasta narkomaanista, joka ei pääse riittävän pitkäkestoiseen päihdepalveluiden laitoshoitoon (Kainulainen 2021). Helsingin Sanomat kirjoittaa siitä, miten naapurustojen jakautuminen hyvä- ja huono-osaisiin vaikuttaa kouluihin ja sitä kautta lasten oppimistuloksiin Helsingin seudulla (Kuokkanen 2021). Tarkastelun kohteena on tällöin etenkin palveluihin pääsyn hankaluudet ja ihmisten tarpeisiin heikosti vastaavat palvelut.

Sanna Marinin hallitusta edeltäneessä hallituksessa eriarvoisuus liitettiin lähinnä työllisyyteen. Perusturvan ja toimeliaisuuden uudistushanke Toimi (2017-2019) keskittyi erityisesti työllisyyteen, minkä kautta hankkeella pyrittiin vähentämään eriarvoisuutta. Palveluiden merkitys eriarvoisuuden vähentämisessä on ollut keskeinen, mutta pandemia toi sen korostuneesti näkyväksi, kun ihmisille tukea antavia palveluita suljettiin väliaikaisesti tai siirrettiin verkkoon. Ymmärrettiin, että koulut eivät ole pelkästään oppimista varten, vaan niiden merkitys on paljon laajempi. Huomattiin myös, miten katkos esimerkiksi mielenterveyspalveluissa hidastaa kuntoutumista. Terveyden ja hyvinvoinnin laitos korostaa, että vaikka virus ei itsessään tuota eriarvoisuutta, niin olemassa olevat yhteiskunnalliset rakenteet voivat synnyttää eriarvoisuutta. Uusi tilanne ja vanhat, osin heikosti toimivat rakenteet lisäävät siten eriarvoisuutta.

Huhtikuussa 2021 julkaistu Sosiaali- ja terveysministeriön suunnitelma (Valtioneuvosto 2021) esittelee keinoja vähentää eri väestö- ja ikäryhmien hyvinvointiin, terveyteen ja turvallisuuteen liittyvää eriarvoisuutta. Siinä eriarvoisuus yhdistetään melko laajasti osallisuuteen, hyviin arkiympäristöihin, hyvinvointia ja terveyttä edistävään toimintaan ja palveluihin sekä päätöksenteon vaikuttavuuteen. Uuden julkisen hallinnan (New Public Governance) suuntaisesti suunnitelman toteuttamisessa korostetaan julkisen, yksityisen ja kolmannen sektorin yhteistyön lisäämistä, ihmisten vaikutusmahdollisuuksien parantamista ja kansalaisyhteiskunnan vahvistamista. Tavoitteet kuulostavat varsin tutuilta ja näyttävät siirtyvän toimenpidesuunnitelmasta toiseen. Eriarvoisuuden ja osallisuuden käsitteitä käytetään väljästi ja ne ovat vaarassa muodostua kuluneiksi hokemiksi, kadottaen ana- 
lyyttista voimaansa ja uskottavuuttaan. Kyetäänkö näiden tavoitteiden avulla aidosti parantamaan niiden ihmisten elämäntilanteita, jotka elävät vaikeissa oloissa?

Eriarvoisuus ja osallisuus ovat käsitteinä keskeisiä ja monimerkityksisiä sosiaalipolitiikan ja sosiaalityön tutkimuksessa. Tässä Januksen numerossa tutkimuksen kohteena ovat eriarvoistavat rakenteet ja toimintamallit. Ulla Halonen, Lina van Aerschot ja Tomi Oinas osoittavat, etteivät palvelut kykene vastaamaan muistisairaiden läheisten tuen tarpeisiin ja että palveluiden paikallinen ja tilannekohtainen vaihtelevuus asettavat palveluiden tarvitsijat eriarvoiseen asemaan. Maija KalmAkubardia kysyy, miten ja miksi venäläisen yhteiskunnan valtaeliitti ohjailee paperittomien toimintamahdollisuuksia. Paperittomien heikot tai lähes olemattomat toimintamahdollisuudet suhteessa valtaväestöön voidaan nähdä yhdenvertaisuuskysymyksenä sekä ratkaisemattomana ihmisoikeuskysymyksenä. Anu Kinnunen ja Osmo Kontula tarkastelevat parisuhteettomien onnellisuustekijöitä vertaillen erityisesti naisten ja miesten välisiä mahdollisia eroja. He osoittavat onnellisuuden rakentuvan monenlaisista tekijöistä ja käy ilmi, että parisuhteettomat naiset ovat keskimäärin parisuhteettomia miehiä onnellisempia. Harriet Tervosen tutkimus avaa lapsuuden turvattomuuden kokemuksia uskonnollisissa perhesuhteissa sekä etenkin omanarvontuntoa kuormittavien ja minäkuvaa rapauttavien tunteiden, kuten häpeän, syyllisyyden ja pelon vaikutuksia ihmisen elämänvalintoihin.

Tutkimusartikkeleiden lisäksi lehdessä on mukana ikääntyneiden asumiseen ja nuorten aikuisten osallisuuteen liittyviä puheenvuoroja sekä kiinnostavia kirjaarvioita sosiaalityön ja sosiaalipolitiikan ytimestä. Tämäkin lehtemme numero osoittaa, miten eriarvoisuus ja sen vähentämiseen suunnatut toimenpiteet muodostavat äärimmäisen tärkeän yhteiskuntatieteellisen tutkimuskohteen.

\section{Minna Zechner \\ Marjo Romakkaniemi}

\section{KiRjallisuUs}

Kainulainen, Jaana (2021) 27-vuotiasta narkomaania pelottaa retkahtaminen, koska hän ei saanut jatkaa laitoshoidossa - päihdepalveluissa on isoja alueellisia eroja. Yle 8.2.2021. https://yle.fi/uutiset/3-11766517 Luettu 10.5.2021.

Kuokkanen, Katja (2021) Naapurustojen jakautuminen hyvä- ja huono-osaisiin vetää syvää railoa koulujen oppimistuloksiin Helsingin seudulla: "Määrittelee oppilaiden koko kouluhistoriaa". Helsingin Sanomat 28.4.2021. https://www.hs.fi/paivanlehti/28042021/art-2000007945015.html Luettu 10.5.2021.

Valtioneuvosto (2021) Hyvinvoinnin, terveyden ja turvallisuuden edistäminen 2030. Helsinki: Valtioneuvosto. https://stm.fi/-/hyvinvointierot-pienemmiksi-vuoteen2030-mennessa Luettu 10.5.2021. 